\title{
Identifying Strategies for English Language Learner Literacy Development at the Secondary Level Using Whole-class Readings
}

\author{
ALICIA TERPSTRA \\ White Pigeon Junior/Senior High School \\ SUSAN R. ADAMS \\ Butler University
}

\begin{abstract}
This study seeks to identify literacy strategies that support English language learner literacy development in secondary English courses. The study occurs over a six-week unit where whole-class reading of the novela Animal Farm takes place. The study features qualitative methods of data collection and analysis situated in an advocacy, change-oriented perspective. Data include teaching journal entries, lesson plans, field notes, student conference interviews (conferring notes), and student records and artifacts. Constant comparison and grounded theory methods of analysis are used, along with open coding and pattern matching. Findings reveal four emergent patterns that support ELL comprehension, participation, and academic achievement: the frequency of teacher readalouds, the use of visual aids with graphic organizers, the use of group activities as part of scaffolding exercises, and sustained repetition of strategies and material.

Keywords: English language learners; literacy strategies; secondary English classroom
\end{abstract}

ITJ, 2019 Volume 16, Number 1 


\section{Introduction}

In this study, secondary English teacher Alicia, first author, sought to identify pedagogical practices that could be implemented in order to foster learning for English language learners (ELLs). While identifying patterns among her struggling students, she noted that students who were English language learners (ELLs) had received the worst marks or had the most missing assignments among their peers. Looking at their coursework over the entire school year, she also noticed that these same students struggled the most during units that encompassed longer works of literature, specifically novels and novelas. Recognizing the possibility that she had perpetuated the pattern of underachievement among her racial minority students, most of whom are also ELLs in her school, she set out to rectify the situation through research.

As a white, female educator, Alicia must remind herself that the mainstream educational and learning standards dominant in American culture to which she is accustomed and considers normal are not the same for all families. Mainstream, white, middle class families typically provide early literacy supports at home from an early age, often by modeling for their children the initiation/reply/evaluation sequence that dominates American school structure (Heath, 1982). By the time these white, middle class children enter school, they have already had sustained experience interacting and performing skills valued by educators (Heath, 1982).

Childhood participation in literacy events is dependent on family and community culture. Because of this, children from other racial and cultural backgrounds may not arrive at school prepared with comprehension skills that teachers and school systems expect because they do not share the same cultural practices as white, middle class households (Heath, 1982). This is not to say that these families and cultures do not value education or literacy; they simply may not 
practice or model understanding in the same way or patterns that schools have traditionally expected.

According to Freeman \& Freeman (2004), ELLs fall into four categories: new students that arrive with adequate school experience, new students that arrive with interrupted school experience, students who have been exposed to two languages simultaneously, and students who are long-term English language learners. Students, like the focal students in this study, arrive in US schools with interrupted formal education (SIFE) and often also have parents who lack English proficiency or have gaps in their own education. It is common for SIFEs to require additional academic assistance (DeCapua, Smathers, \& Tang, 2007).

Because three female ELL students share the same class period, Alicia decided to narrow the scope of her research to the academic needs of these specific students. Graded assignments, teacher notes and observations, and student surveys indicated these students struggled during sustained reading units, so she constructed this study to coincide with a unit that involved a whole-class reading of a novela. Her goal for all students during the unit was to support and foster learning habits that help students understand and recognize academic language and constructs in order to develop and support literacy and higher-order thinking processes. Her goal for the research was to answer the inquiry of equity question she formed concerning the three females:

What approaches, strategies, and activities can secondary English educators implement to improve the academic performance and participation of second and third-generation, female English language learners while reading whole-class novels? 


\section{Literature Review}

\section{Teaching Strategies and Practices for ELLs}

Education plays a vital role in facilitating future success for high school students, as well as fostering individual growth and social interaction. The reading, writing, speaking, and listening strategies taught in the school curriculum are fundamental in the development of identity and preparation for adult life. As both Chamot and O'Malley (1994) and Echevarría and Graves (1998) have long emphasized, academic language development, especially at the secondary level, is necessary for ELLs to utilize higher-order cognitive strategies to compare, contrast, debate, evaluate, analyze, and synthesize information. These are complex processes; supporting student comprehension at the secondary level requires that teachers utilize specific pedagogical methods that foster content retention and academic language comprehension.

When Alicia crafts a lesson or unit for her classroom, it is often her goal to facilitate flow experiences (Csikszentmihalyi, 1990), in order to foster engagement and performance. When students enjoy a lesson, they are more likely to become engaged, learn the material, and retain what they have learned. Studies show that for all students, including ELLs, the level of reading engagement during reading activities is even more important than socioeconomic status in determining literary performance (OECD, 2009). Students are more likely to be interested in topics that can be directly connected to their own culture, interests, experiences, and knowledge. Students' cultures provide the real world experiences that they relate learning to in order to make meaning; these sources affirm students' identities and help the students see themselves as learners and critical thinkers (Heath, 1982; Chun, 2009). Connecting student interests and experiences led Alicia to theorize that the ELLs would perhaps stay engaged in reading for 
longer periods of time and at deeper comprehension levels if they experienced flow during reading.

According to Csikszentmihalyi (1990), humans achieve a state of happiness that comes when they are fully involved in something meaningful. When people experience an activity that captures their attention to the point where nothing else seems to matter, a flow experience occurs (Csikszentmihalyi, 1990). If you have ever been so caught up in reading a book that you have lost track of time, you have experienced flow. It is during flow experiences that authentic engagement and learning ensues. In the classroom, flow occurs when learners a) have a sense of control and competence, b) are presented a challenge that requires a level of skill that is neither too easy nor too difficult, c) have clear goals and feedback, d) have a focus on the immediate experience (Csikszentmihalyi, 1990). Smith and Wilhelm (2006) emphasize that a positive social experience helps students engage and experience flow.

The biggest challenge and difficulty in fostering engagement and flow is providing students with both a sense of competence and challenge. If an activity or lesson is too easy or too difficult students will struggle to engage. Educators must find the proverbial "sweet spot" of learning for each student that finds the middle ground between "I can't, it's too hard" and "This is easy and boring." Scaffolding is a support technique that provides activities and strategies that help students accomplish tasks that would be impossible otherwise (Graves \& Graves, 2003). Teachers use scaffolding strategies, such as activating prior knowledge, establishing purpose, or using visual aids, to help students master and learn new practices, which affirms their abilities and provides a sense of accomplishment (VanDeWeghe, 2008). When students are offered the right amount of challenge, a conceptual space known as the zone of proximal development (Vygotsky, 1978) is created for the learner. It is within the zone of proximal development that 
students feel both the sense of challenge and the confidence of success necessary to experience flow. This is difficult to achieve since an individual's learning preferences and identity are not fixed; they change constantly depending on a wide variety of conditions (Moje \& Luke, 2009). In order to ensure that students have the competency needed to achieve academic goals, many educators advocate the use of gradual release of responsibility (GRR) scaffolding techniques (Fisher \& Frey, 2008). One form of GRR that Alicia implements in her classroom is the Optimal Learning Model (OLM). The OLM requires that teachers support and move students to independent practice through a series of demonstrations and explanations (Routman, 2018). Both GRR and OLM techniques follow the same steps: The teacher will first provide explanations and model the strategy for students. Next, students participate in the strategy under the teacher's guidance. Afterward, the students will undergo guided practice while the teacher provides support and feedback; finally, after watching the teacher, helping the teacher, and being helped (as needed) by the teacher, the students will independently complete the work (Fisher \& Frey, 2008; Routman, 2018). OLM, however, features repetition of steps. The amount of repetition needed varies student by student and lesson by lesson. The teacher must observe carefully and check for comprehension frequently to ensure that ELLs understand and are engaged.

Reading aloud to students provides strong modeling for reading fluency and expression of intonations and punctuation, along with informational processing skills (Trelease, 1989). Teachers who model appropriate reading strategies during read-alouds encourage students to make predictions, activate prior knowledge, and connect ideas across texts (Davey, 1983). ELLs in particular need strategies that focus on oral and academic language development (Samson \& Collins, 2012). When ELLs struggle with reading, the best practice is to match their capabilities 
and needs to reading instruction that fits the most appropriate environment (International Reading Association, 2003). Read-alouds satisfy the majority of these requirements, allowing students guided practice, scaffolded support, and the ability to remain in the classroom environment. Studies (OECD, 2015) show that girls typically outperform boys in reading, so reading aloud may offer increased support for male students in particular, especially those who benefit from auditory learning.

\section{Academic Challenges of ELLs}

Despite years of research and reform, patterns of academic success and failure based on a student's socioeconomic status, race, and language have remained consistent (Friedrich \& McKinney, 2010). Many children from poor and minority families have not had the same exposure to high quality preschool experiences that white and higher socioeconomic status children have had (International Reading Association, 2003). By the time these children enter kindergarten there already exists an achievement gap between them and their white, mainstreamculture, middle-class peers (Heath, 1982; Isaacs, 2012).

In additional to cultural norms and expectations, ELLs face the challenge of developing English language competency while also acquiring content knowledge. Historically, ELL students' academic achievement has lagged behind that of their native-English speaking peers (Strickland \& Alvermann, 2004). While some ELLs' families have only recently immigrated to the United States, this is not always the case. $57 \%$ of adolescent learners classified as limited English proficient were born within the United States and are second or third-generation residents (Batalova, Fix, \& Murray, 2007). Educators have found that students born in the United States may belong to families and communities that have maintained strong connections to their native language (Sandefur, Watson, \& Johnston, 2007). These are American citizens that are 
entering the educational system with diverse cultural values and language proficiencies. Because their strengths and abilities do not conform to mainstream cultural values, ELLs are often not properly identified or are sometimes placed in mainstream classrooms without adequate language support (Samson \& Collins, 2012), hence the achievement gap between ELLs and mainstream, middle-upper class students widens as years pass. Worse still, some administrators and teachers have lowered expectations for ELLs and limit which courses are available for enrollment (Moll, 1992).

When we specifically look at ELLa' struggles with literacy, studies show that mastery of a student's first language influences their ability to acquire literacy in English (Odlin, 1989). Schools that provide literacy instruction in a child's home language or through bilingual content instruction support and accelerate ELL academic learning (Eisenchlas, Schalley, \& Guillemin 2013; Makin, Campbell \& Jones Diaz, 1995; DeCapua, Smathers, \& Tang, 2007). When students are not adequately supported, their ability to master oral language skills or academic skills in English is reduced (Nystrand, 1997). By the time these students reach high school their speaking, writing, and reading comprehension abilities are often several grade levels behind their peers. For these reasons, it is important that educators attain foundational knowledge about ELL students in order to meet their needs. Sadly, in school districts like Alicia's in which small numbers of ELLs are enrolled, providing teacher supports and high quality professional development is often not a high priority (Samson \& Collins, 2012). Alicia noticed that when resources were provided to her, she often felt overwhelmed and unsure where to begin. 


\section{Methods}

\section{Context of the Study}

Located in rural Indiana, Rural High School ${ }^{1}$ (RHS) is the sole high school in the district and the only public high school located in this small Indiana city. This study occurred over a 6-week unit that covered a whole-class reading of the novela, Animal Farm (Orwell, 1996). Alicia was the primary teacher for $10^{\text {th }}$ grade English at RHS, and all classes in the regular English course participated in the unit. During the course of the study, she focused on the academic needs of three female students: Esperanza, Valeria, and Amelia ${ }^{2}$. All three were in the same English class. The class itself was composed of 16 students. Six of the students in the class were male and ten were female. The class was $62.5 \%$ White, $18.75 \%$ Hispanic, and $18.75 \%$ Multiracial. All students were between the ages of 15-17.

While two males in the class also identify as Hispanic, both were raised in English-only speaking households, both maintained above-average grades in English, and neither qualified for or needed ELL support. The three females in the study were raised in households that predominately spoke Spanish, met Indiana requirements for receiving ELL support, and were struggling to maintain passing grades. Because of the difference in demographics and the academic needs of the female students, Alicia selected them as the focal point of the study.

Alicia, the instructor for this study has seven years of teaching experience. Like $76 \%$ of the U.S. teaching population, she identifies as female (U.S. Department of Education, 2018). She is white, in her mid-thirties, and from a middle-class background. Susan, the second author on this paper, served as Alicia's master's thesis supervisor. 


\section{Data Sources and Analysis Methods}

Data sources for this study included professional teaching journal entries, lesson plans, field notes, student conference interviews (conferring notes), and student records and artifacts. The method of data collection and analysis was a qualitative approach situated in an advocacy, change-oriented perspective (Creswell, 2003). Because this study was centered on a detailed, indepth examination of a specific group and situation, analytical procedures that are commonly used with case studies were implemented (Shagoury \& Power, 2012). Samples of analysis materials are provided in the Appendices.

Case student conferences during the unit were a mix of ethnographic and semi-structured interviews; ethnographic questions (Spradley, 1979) allowed participants to express and build their own schemes and classifications (See Appendix C and E). This was paired with prepared questions that allowed Alicia to keep the conference responses focused on matters relating directly to the research questions (Anderson, Herr, \& Nihlen, 2007) (See Appendix E). Field notes include records of what Alicia observed, heard, experienced, and thought during class activities, along with notes on student artifacts and participation (Burnaford, Fischer, \& Hobson, 2001) (See samples in Appendix B). Student artifacts (See Appendix F for a sample) were a primary source of data that provided tangible evidence and data concerning the range of student comprehension and ability in relation to the goals of the task and study (Shagoury \& Power, 2012).

Throughout the unit students were assigned to complete activities that required them to track story events and analyze story plots using graphic organizers created as a hybrid of story mapping and Cornell notes. The decision to create a graphic organizer using these strategies was deliberate and born from abundant research that suggests visual representations and graphic 
organizers help increase comprehension for ELLs (Eschevarria \& Graves, 1998; Chun, 2009). Alicia noticed patterns from earlier units that indicated traditional note-taking strategies were not working for Esperanza, Valeria, and Amelia. All three students had multiple missing note-taking assignments. Each reported that the notes only "somewhat" helped them understand or retain key ideas, key information was missing from their notes, and each had received poor test and quiz scores. These patterns led Alicia to theorize that the note-taking strategies she used in those units were ineffective for ELL students. For the purpose of this study, she created a different method of note taking to observe the effect it would have, if any, on lesson completion and comprehension of the focal students.

All students completed journaling exercises twice weekly during the unit. The first journal prompt of the week focused on personal connections and reactions to events in the text. The second journal entries for the week were focused on plot and allegorical connections. Along with regular journaling, students were given the following activities:

- Story mapping and annotations for each chapter;

- Multiple choice chapter quizzes;

- In-class discussion and debate exercises;

- Three assignments on understanding and using allegory;

- Three assignments on understanding and using satire; and

- A final test that included multiple choice plot questions, short answer, and essay options that tested higher-order analytical comprehension.

Students were also assigned their choice from a list of end-of-unit projects that allowed them to demonstrate their understanding of authorial intent and social commentary. 
Alicia felt strongly that she ought to revise and implement strategies based on student needs, but prior to this study, those decisions were made more intuitively than by deep observation and analysis. For this study, Alicia analyzed focal student assignments by coding for themes and by spending time reflecting on student work using constant comparison and grounded theory as each assignment was collected (Anderson, Herr, \& Nihlen, 2007). Her initial step was to read each document and then to segment student responses into categories for indepth analysis and comparison (Maxwell \& Miller, 2008). Open coding and pattern matching to create taxonomies of strategies that worked and those that did not work was the primary approach (Lankshear \& Knobel, 2004). Taxonomic categories were organized based on semantic relationships found in student artifacts, field notes, teacher journals, and conferring interviews.

Because the goal of the study was to identify and separate successful strategies from nonsuccessful ones, Alicia did not use predetermined categories for analysis; instead, she began analysis by simply asking herself, "What do I notice?" (Charmaz, 2006). Using categorical analysis (Fetterman, 1998; Coffey \& Atkinson, 1996, as cited in Lankshear \& Knobel, 2004), she separated the focal students' work into three simple categories: Completed-Well, Completed-Not Well, and Not Completed. From these categories she looked for patterns; she compared the three focal students' work to see what they had in common and what differences arose. After categories were identified, Alicia analyzed connections between the sets and context of the research (Anderson, Herr, \& Nihlen, 2007).

As she analyzed and coded data, Alicia marked event codes, activity codes, and methods codes to help keep track of frequency of patterns (Falk \& Blumenreich, 2005) (See Appendix A). This allowed her to track how regularly particular codes (e.g. class participation, assignment completion) appeared throughout the unit. As she analyzed and identified patterns and behaviors, 
Alicia triangulated data to confirm initial findings by cross-referencing codes through conducting and analyzing student interviews and by analyzing her journal, field notes, and other student artifacts (See Appendix B and Appendix D).

\section{Findings and Discussion}

Analysis of data revealed four teacher contributions that seemed to have a positive effect on ELL comprehension, participation, and academic achievement: teacher read-alouds, the use of visual aids with graphic organizers, the use of group activities as part of scaffolding exercises, and sustained repetition of strategies and material.

\section{Read-Alouds}

Some secondary educators assume incorrectly that high school students no longer need to hear the text read aloud by their teacher, yet early indications from focal students indicated that they not only appreciated this support, but also benefitted from it by their own estimation.

Research supports this approach for all students (Trelease, 1989; Davey, 1983). For this unit Alicia decided to read aloud approximately half the novela to all students. She carefully determined what portions of the text she would read and what strategies she would model. She also made sure that students had clear goals and expectations for their independent reading in order to help them identify what was important in the text.

Valeria benefited the most out of the three students. Her journal responses and quiz grades were higher for sections of the text that were read aloud versus the portions of the story where she read independently (See Appendix B). Alicia noticed during conferring and in journal entries that Valeria would commonly confuse character names and actions for portions of the story that she read independently (See Appendix D). Esperanza also had better scores on quizzes with information that was read aloud versus silently. She wrote almost exclusively in journal 
entries about the read-aloud portions of the text and her reflections were more cohesive and showed deeper understanding than reflections on independent reading (Student Journal Entry). When during a conference why Esperanza wrote the most about the portions that Alicia read aloud, Esperanza responded that she had an easier time picturing and hearing the story when Alicia read because of the inflections she used (January 15, 2019, Teacher Journal).

Alicia was not able to identify any dominant pattern that emerged between silent reading and read-alouds with Amelia. She completed assignments and participated in activities during days when students read silently and days where Alicia read aloud; Alicia was unable to identify any particular concept or area that indicated why or when Amelia struggled. During conferences Amelia claimed she preferred it when Alicia read because it was easier, but she could not articulate what specifically about the read-alouds made it easier. Alicia noticed Amelia sometimes seemed distracted during silent reading, but this is fairly normal for all students in Alicia's experience. There was no indication in Amelia's work, her notes, or from conversations with Alicia that indicated Amelia had a problem refocusing attention (See Appendices A, B, and C).

\section{Graphic Organizers}

A driving force behind Alicia's desire to study her ELL students was the realization that her traditional teaching methods were not working for them. For years Alicia taught her students to use Cornell notes, Venn diagrams, and T-charts as graphic organizers to take notes, summarize, and practice reading strategies like comparing and contrasting, identifying order of importance, and textual analysis. However, when Alicia would check student notes for completion or understanding, all three of the students in this study frequently had incomplete or only partially complete notes. When Alicia asked during conferences how helpful the notes were 
and why they struggled to complete them, focal students gave various answers such as having difficulties remembering what part of the story the notes took place in, what characters the notes were about, or how the notes helped provide answers for assignments. Essentially, all three indicated that they viewed the notes as busy work more than a helpful practice (January 18, 2019, Teacher Journal Notes).

Having already noticed this pattern before the study began, Alicia started the unit with a new graphic organizer activity. Alicia still felt the recall/synthesis portion of the Cornell system was important, but Chun (2009) cites the importance of visual aids in facilitating reading comprehension for ELL students, so she created a graphic organizer that was a bridge between the two. Taking a sheet of paper, Alicia drew a line that kept the left 2.5 inch margin blank for student notes. The remainder of the paper students used for story mapping. After a discussion of each chapter in which the students discussed what they felt the most important events of the chapter were, they drew visual representations of the scenes on the paper in graphic novel fashion. Then in the left margin, students wrote descriptions of what was happening and why they felt it was important. A sample of story mapping has been provided in Appendix F.

Initially, Alicia met some resistance to this form of graphic organizer. Students complained that they were not good artists or that it took so much extra time to do. However, after practicing it a few times they began to enjoy the process. They informally competed to see who could draw the best (and worst) pictures. Students actively discussed during their reading time which parts merited drawing. They also evaluated the importance of various scenes to determine which details belonged in the left-hand column.

The difference in student performance patterns between the previous approach and the story mapping Cornell notes hybrid was noticeable. Esperanza improved from rarely completing 
notes to completing them the majority of the time (See Appendix A and B). Amelia completed $100 \%$ of note-taking activities, and Valeria only missed two. During individual conferences all three claimed they preferred the new method to the older way. Valeria even confessed that when she was absent and missed a reading session that she used the story map from another student to catch up on what happened. The only negative outcome that Alicia was able to discern from the unit was that students sometimes drew only partial scenes or failed to finish drawing all of the scenes the class decided were needed. This usually occurred when students were putting in extra effort to draw well, perhaps devoting too much time and energy to creating art rather than simply creating sketches to support memory and to indicate comprehension.

\section{Group Activities}

Existing research (DeCapua, Smathers, \& Tang, 2007; Fielding \& Pearson, 1994; Au, 1998) that indicates the effectiveness of group work on academic success and language development inspired Alicia to implement group work early in this unit in spite of her initial reluctance. Previously group work had been frustrating in her classroom as she watched one or two students complete work for their group while others watched.

Predetermining and purposely selecting the pairings beforehand based on student need and abilities was key (Jones-Smith, 2011). Alicia paired her ELL students with classmates that were native English speakers who had a history of working well with ELLs. She also chose to implement group work during specific scaffolding routines. A pattern that Alicia noticed in her teacher journal and gradebook was that all three of the female students in the study completed assignments most often when they were done in groups. Focal students also said during conferences that they liked the help that their peers offered during group work. However, Alicia 
also had recorded numerous occasions when the effort put forth by each student in a group was disproportionate.

To try to satisfy the need for students to work authentically and fairly, but also have the opportunity to help support each other's understanding, Alicia decided to add a group participation step into the OLM directly before the step where students work independently. Now the process would follow five steps: Teacher demonstrates, students watch; teacher demonstrates, students help; students lead, teacher helps; students work in groups, teacher helps as needed; students work independently, teacher monitors. With this pattern students had the opportunity to help each other, but also had the independent practice that demonstrated their mastery.

Amelia and Valeria showed the greatest pattern of improvement using this strategy. Esperanza only participated in group activities approximately half the time, but could not articulate what influenced her participation or nonparticipation in particular. Alicia's observational notes indicate that on days when Esperanza did not participate in group activities her mood appeared withdrawn. There might have been personal issues that affected her, but she chose not to share that information if it were the case.

All three ELLs indicated during conferences that they felt the group activities helped them understand lessons and strategies. The group activities that they voiced highest approval of were activities that allowed them to move around the room and featured some sort of challenge (e.g. finding printed character attributes hidden around the room that they had to place in order of importance). Although not the focus of this study, male students also responded positively to this strategy as well; a significant number showed improvement in test and quiz scores when compared with previous units. 


\section{Sustained Repetition}

Esperanza and Valeria struggled with focusing and remembering particular lessons, plot points, or strategies. When Alicia began integrating the additional step into the OLM, she noticed that the ELLs' academic performance increased. Alicia wondered if it was perhaps due to the increased repetition of using a particular strategy. Alicia decided to experiment with reviewing specific concepts and strategies every few days following the advice of Kang (2016) to see how well the focal students could recall and retain these concepts and strategies. During the prereading activities of the unit, students were introduced to the literary concept of allegory and then were tasked with finding an allegorical children's story to read and analyze. When she reviewed the definition and purpose of allegory a week-and-a-half later, Alicia was disappointed to discover that only a few students could remember. Alicia began intentionally mentioning allegory and traced the story's allegorical connection every other day. She checked in with the focal students every Friday to see how well they could explain allegory and identify where it was present in the story.

Amelia could recall most quickly; by the second week (after three in-class repetitions) she could define allegory and explain which parts of Animal Farm were allegorical. Esperanza could recall the definition of allegory by week three (after six in-class repetitions), and could recall main allegorical events by week four. Valeria took the longest to recall definitions and events. She struggled to remember allegory until week four, and still struggled to recall roughly half the allegorical events by the end of the unit. While there was not a discernable pattern that identified specifically how many times the focal students needed a particular concept or event repeated, both Valeria and Esperanza required more repetitions than any of the other students in the class with the exception of students with specific learning disabilities. 


\section{Limitations}

While Alicia was able to support academic comprehension and participation among the ELL students in the study, it is impossible to claim that these findings may transfer successfully to other settings. The individual needs of each learner are complex and ever changing; no two students may necessarily respond the same way to the same strategy. The implementation of multiple strategies interwoven throughout the unit make direct correlation of strategy to outcome difficult, if not impossible. The study group that was the focus of the unit was small, and while Alicia was able to achieve positive outcomes with her students, overarching causality between the implemented strategies and all ELLs cannot be claimed. Every classroom, teacher, and ELL is unique; these strategies may not achieve the same outcomes in every context. However, the findings may prove instructive to educators of ELLs with similar challenges.

\section{Classroom Implications}

The goal of the study was to better understand which particular practices and strategies might help secondary teachers foster success for ELL students. Overall, analysis showed a positive connection between ELL students' academic performance and the use of read-alouds, graphic organizers with visual mapping, purposeful grouping exercises, and intentional repetition of content and activities. Although it is beyond the scope of this study, Alicia was interested to note that the male ELL students in her classes also showed improved academic improvement during this study. It is difficult to determine if one strategy was more effective than any other because the nature of the unit intertwined the strategies collectively throughout the study period. It is also challenging to assign order of importance due to the multiplicity of identity and support needs that learners in the study possess. An individual's learning needs and identity are not stable 
and unchanging; they are in constant flux and development depending on particular contexts and situations (Moje \& Luke, 2009).

Despite being unable to determine the overall effectiveness of each individual strategy, existing research supports the practice of all four. The use of graphic organizers, textual outlines, and rewriting/summary texts is a suggested strategy for supporting ELL students' literacy comprehension (Echevarría \& Graves, 1998). Multimodal texts, especially texts that provide visual aids, foster engagement and literacy proficiency among English language learners (Chun, 2009). By combining story mapping and Cornell note-taking strategies, students were able to develop recall abilities in combination with textual analysis. The focal students in this study found the visual strategy more engaging, and reported that the method was more beneficial than traditional Cornell notes. Alicia did not detect any pattern that indicated a decline in non-ELL students' understanding when using story-mapping techniques in place of traditional notes, but she did have to allow students more time to complete the note-taking activities. When asked how likely they might use the note-taking method outside of class time however, the majority of students admitted they were more likely to revert to traditional methods due to the increased time required for story maps. It is our conviction that making time for story mapping and requesting that students use the approach regularly would address these concerns.

Conversation is vital for English language learners. Alicia chose to limit the size of group activities to no more than three students to allow for easier exchanges and greater participation (Nystrand, 1997). By placing group activities in the middle of scaffolding exercises, students had the opportunity to share prior knowledge, predictions, questions, summaries, and general ideas about strategies and readings (Sandefur, Watson, \& Johnston, 2007). The collaborative social environment not only supports language development and comprehension (Au, 1998; 
Vygotsky, 1978; Fielding \& Pearson, 1994), but also served to boost student esteem and communal relationships that support academic goals (Jones-Smith, 2011). The spaced repetition of scaffolding activities and content also supports text recall, problem solving, and generalization to new situations (Kang, 2016).

The decision to base the unit around a whole-class novela may also have contributed to the success of the unit, especially the group scaffolding exercises. While there is much literature that supports the use of self-selected novel units (Fielding \& Pearson, 1994; Johnson \& Blair, 2003), the whole-class reading experience helps to build critical thinking skills and foster class community. Class discussions and group interactions were easier to plan, implement and facilitate when every student read the same material and in the same time period. Students were also able to share their thoughts and make direct, explicit connections to the text. As frequently happens during whole-class discussions, a pattern of limited participation among a few students developed, however participation among all students was increased during small group exercises in spite of this. This increase in participation leads us to theorize that the small group scaffolding exercises could also work effectively with small groups reading self-selected novels using book club or literature circle approaches and merits future study.

\section{Conclusion}

Alicia developed this study with the goal of identifying specific strategies she could implement to increase the academic performance of ELLs. By the end of the unit the focal students had improved their grades, had improved the frequency with which they completed assignments, and had increased their participation in class activities. Alicia will continue to use read-alouds, story mapping in combination with Cornell notes, group activities as part of the OLM, and spaced repetition of content and strategies. Continued research and practice of these approaches may 
confirm these strategies as viable and beneficial for other secondary English teachers to practice with ELLs in high school English/Language Arts contexts.

\section{ABOUT THE AUTHORS}

Alicia Terpstra, M.S. is a graduate of the Teachers College, Ball State University where she completed a B.S. in secondary English education. She is a 2019 graduate of the Master's in Effective Teaching and Leading (METL) the Butler University College of Education. A former English teacher and department chair at Rensselaer Central High School High School, Indiana, Ms. Terpstra currently teaches English at White Pigeon High School, Michigan.

Inquiries should be directed to: Alicia.terpstra@gmail.com

Dr. Susan Adams is Associate Professor of Middle/Secondary Education at Butler University. A former high school ESL and Spanish teacher and instructional coach, Dr. Adams earned her Ph.D. in Literacy, Culture, and Language in Education from Indiana University. Susan's publications are included in Theory into Practice, English Journal, SAGE Sociology of Education, EBSCO Research Starters, and The New Educator. Her book, Race and Pedagogy: Creating Collaborative Spaces for Teacher Transformations (2016) was co-authored with Jamie Buffington-Adams.

Inquiries should be directed to: sradams@,butler.edu

\section{References}

Anderson, G. L., Herr, K., \& Nihlen, A.S. (2007). Studying your own school: An educator's guide to practitioner action research. Thousand Oaks, CA: Corwin Press.

Au, K.H. (1998). Social constructivism and the school literacy learning of students of diverse backgrounds. Journal of Literacy Research, 30(2), 297-319. http://dx.doi.org/10.1080/10862969809548000

Strategies for ELs at secondary level 
Batalova, J., Fix, M., \& Murray, J. (2007). Measures of change: The demography and literacy of adolescent English learners. New York, NY: Migration Policy Institute, Carnegie Corporation. Retrieved from https://www.colorincolorado.org/research/measures-changedemography-and-literacy-adolescent-english-learners

Burnaford, G., Fischer, J., \& Hobson, D. (2001). Teachers doing research: The power of action through inquiry (2nd ed.). Mahwah, NJ: Lawrence Erlbaum Associates.

Chamot, A.U., \& O’Malley, J.M. (1994). The CALLA handbook: Implementing the cognitive academic language learning approach. New York, NY: Addison-Wesley.

Charmaz, K. (2006). Constructing grounded theory: A practical guide through qualitative analysis. London: Sage.

Chun, C.W. (2009). Critical literacies and graphic novels for English-language learners: Teaching Maus. Journal of Adolescent \& Adult Literacy, 53(2), 144-153. http://dx.doi.org/10.1598/JAAL.53.2.5

Creswell, J. W. (2003). Research design: Qualitative, quantitative, and mixed methods approaches. Thousand Oaks, CA: Sage Publications, Inc.

Csikszentmihalyi, M. (1990). Flow: The psychology of optimal experience. New York, NY: Harper \& Row.

Davey, B. (1983). Think Aloud: Modeling the Cognitive Processes of Reading Comprehension. Journal of Reading, 27(1), 44-47. Retrieved from http://www.jstor.org/stable/40029295

DeCapua, A., Smathers, W., \& Tang, F. (2007). Addressing the challenges and needs of students with interrupted formal education (SIFE). Educational Policy \& Leadership, 65, 40-46. https://doi.org/10.5054/tj.2010.214878

ITJ, 2019 Volume 16, Number 1 
Echevarría , J., \& Graves, A. (1998). Sheltered content instruction: Teaching English-language learners with diverse abilities. Boston, MA: Allyn \& Bacon.

Eisenchlas, S. A., Schalley, A. C., \& Guillemin, D. (2013). The Importance of Literacy in the Home Language: The View from Australia. SAGE Open. http://dx.doi.org/10.1177/2158244013507270

Falk, B. \& Blumenreich, M. (2005). The power of questions: A guide to teacher and student research. Portsmouth, NH: Heinemann.

Fetterman, D. (1998). Ethnography: Step by step, $2^{\text {nd }}$ Edition. Newbury Park, CA: Sage.

Fielding, L.G., \& Pearson, P.D. (1994). Synthesis of research/Reading comprehension: What works. Educational Leadership, 51(5), 62-68. Retrieved from http://www.ascd.org/publications/educational-leadership/feb94/vol51/num05/Synthesisof-Research- -Reading-Comprehension@-What-Works.aspx

Fisher, D., \& Frey, N. (2008). Homework and the gradual release of responsibility: Making “responsibility” possible. English Journal 98(2), 40-45. Retrieved from https://dpi.wi.gov/sites/default/files/imce/ela/resources/Fisher_and_Frey_Homework.pdf

Freeman, Y., \& Freeman, Y. (2004). Struggling English language learners: Keys for academic success. TESOL Journal, 12(3), 18-23. http://dx.doi.org/10.1002/j.1949$\underline{3533.2003 . t b 00136 . x}$

Gallagher, K. (2009). Readicide: How schools are killing reading and what you can do about it. Portsmouth, NH: Stenhouse Publishers.

Graves, M.F., \& Graves, B.B. (2003). Scaffolding reading experiences: Designs for student success. Norwood, MA: Christopher-Gordon 
Heath, S. (1982). What no bedtime story means: Narrative skills at home and school. Language in Society, 11(1), 49-76. Retrieved from https://people.ucsc.edu/ gwells/Files/Courses_Folder/documents/Heath.BedtimeStories.p $\underline{\mathrm{df}}$

International Reading Association. (2003). The role of reading instruction in addressing the overrepresentation of minority children in special education in the United States. Retrieved from https://www.literacyworldwide.org/docs/default-source/where-we$\underline{\text { stand/minority-children-position-statement.pdf?sfvrsn=dc4ea18e } 6}$

Isaacs, J.B. (2012). Starting school at a disadvantage: The school readiness of poor children. Brookings Institution. Retrieved from https://www.brookings.edu/wpcontent/uploads/2016/06/0319_school_disadvantage_isaacs.pdf

Jones-Smith, E. (2011). Spotlighting the strengths of every single student: Why U.S. schools need a new, strengths-based approach. Santa Barbara, CA: Praeger.

Kang, S.H.K. (2016). Spaced repetition promotes efficient and effective learning: Policy implications for instruction. Instructional Strategies, 3(1), 12-19. http://dx.doi.org/10.1177/2372732215624708

Lankshear, C., \& Knobel, M. (2004). A handbookfor teacher research. Milton Keynes, UK: Open University Press.

Johnson, D., \& Blair, A. (2003). The importance and use of student self-selected literature to reading engagement in an elementary reading curriculum. Reading Horizons, 43(3), 182202. Retrieved from https://scholarworks.wmich.edu/reading_horizons/vol43/iss3/3 
Makin, L., Campbell, J., Jones Diaz, C. (1995). One childhood, many languages: Guidelines for early childhood education in Australia. Pymble, New South Wales, Australia: Harper Educational.

Maxwell, J. \& Miller, B.A. (2008). Categorizing and connecting strategies in qualitative data analysis. Handbook of Emergent Methods, 461-477.

Moje, E.B., \& Luke, A. (2009). Literacy and identity: Examining the metaphors in history and contemporary research. Reading Research Quarterly, 44(4), 415-437. http://dx.doi.org/10.1598/RRQ.44.4.7

Moll, L.C. (1992). Bilingual classroom studies and community analysis: some recent trends. Educational Research, 21(2), 20-24. https://doi.org/10.3102/0013189X021002020

Nystrand, M. (1997). Opening dialogue: Understanding the dynamics of language and learning in the English classroom. New York, NY: Teachers College Press.

Odlin, T. (1989). Language transfer: Cross-linguistic influence in language learning. New York, NY: Cambridge University Press.

OECD. (2016). PISA 2015 results (Volume I): Excellence and equity in education. Paris, France: PISA, OECD Publishing. https://doi.org/10.1787/9789264266490-en

OECD. (2009). PISA 2009 results (Volume III): Learning to learn: Student engagement, strategies and practices. Paris, France: PISA, OECD Publishing. https://doi.org/10.1787/9789264083943-en

Orwell, G. (1996). Animal farm: A fairy story. New York, NY: Signet Classics.

Routman, R. (2018). Literacy essentials: Engagement, excellence, and equity for all learners. Portland, ME: Stenhouse Publishers. 
Samson, J.F., \& Collins, B.A. (2012). Preparing all teachers to meet the needs of English language learners: Applying research to policy and practice for teacher effectiveness. Washington, DC: Center for American Progress. Retrieved from https://www.americanprogress.org/issues/education-k12/reports/2012/04/30/11372/preparing-all-teachers-to-meet-the-needs-of-englishlanguage-learners/

Sandefur, S. J., Watson, S.W., \& Johnston, L.B. (2007). Literacy development, science curriculum, and the adolescent English language learner: Modifying instruction for the English-only classroom. Multicultural Education, 14(3), 41-50. Retrieved from https://go.gale.com/ps/anonymous?id=GALE\%7CA163265166\&sid=googleSchola $\underline{\mathrm{r} \& \mathrm{v}=2.1 \& \mathrm{it}=\mathrm{r} \& \text { linkaccess }=\mathrm{abs} \& \mathrm{issn}=10683844 \& \mathrm{p}=\mathrm{AONE} \& \mathrm{sw}=\mathrm{w}}$

Shagoury, R. \& Power, B.M. (2012). Living the questions: A guide for teacher-researchers (2nd ed.). Portsmouth, NH: Stenhouse Publishers.

Smith, M.W., \& Wilhelm, J.D. (2006). Going with the flow: How to engage boys (and girls) in their literacy learning. Portsmouth, NH: Heinemann.

Spradley, J. P. (1979). The ethnographic interview. New York, NY: Holt, Rinehart and Winston. Strickland, D.S., \& Alvermann, D.E. (Eds). (2004). Bridging the literacy achievement gap grades 4-12. New York, NY: Teachers College Press.

Trelease, J. (1989). The new read-aloud handbook. New York, NY: Penguin Books.

U.S. Department of Education, National Center for Education Statistics. (2018). Digest of Education Statistics, 2016 (NCES 2017-094), Introduction and Chapter 2. Retrieved from https://eric.ed.gov/?id=ED580954 
VanDeWeghe, R. (Ed). (2008). Research Matters. English Journal, 97 (4), 93-96. Retrieved from http://www.jstor.org/stable/40503399

Vygotsky, L.S. (1978). Mind in society: The development of higher psychological processes.

Cambridge, MA: Harvard University Press.

Strategies for ELs at secondary level 


\section{APPENDIX A}

\section{Analysis of Focal Student Completion and Performance on Assignments and In-Class Activities}

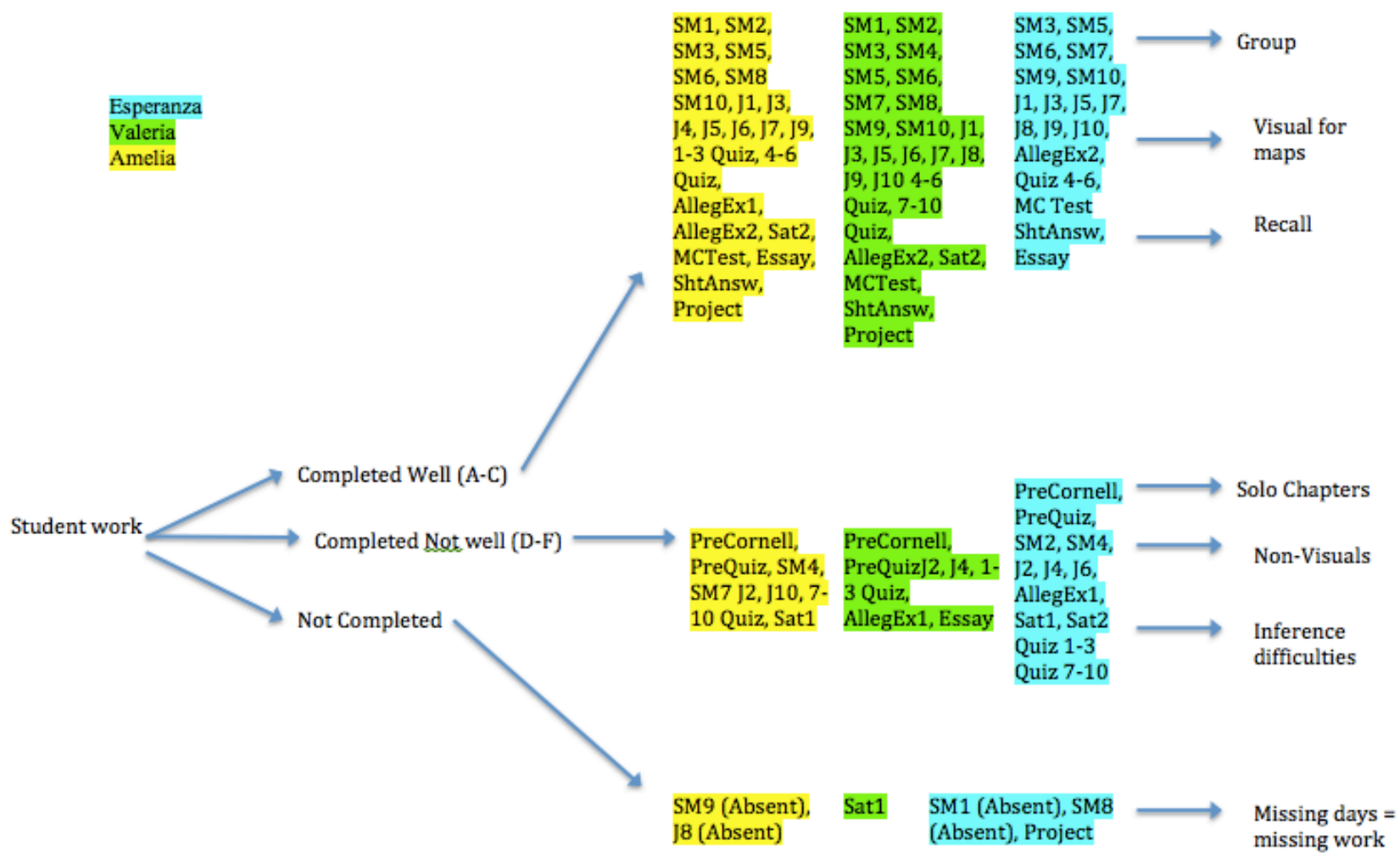

\section{APPENDIX B}

\section{Sample Teacher Notes from Focal Student Interviews}

\section{$2 / 2 / 19$}

\section{Valeria}

What was going well/what she liked: Character voices and emotions. Easier to tell characters apart when she hears it. Asked if she gives characters different voices in her mind when she reads silently. Says sometimes. Asked if she knows why it works sometimes and why not other 
times. Depends on how easy the chapter is to read. Hard if she has to stop a lot. Asked how often she has to stop. Says it depends. Asked if the story mapping was helping to keep track of plot. Said yes, but that she sometimes gets bored with drawing scenes. I wonder if I'm giving them too many panel options or is she trying to draw too much detail? Pulled out her story map from last chapter. Starts very detailed, get simpler (stick figures). Maybe practice picture doodling to help students get a feel for it?

Asked what was confusing or annoying about the unit: Doesn't understand why the characters are animals. Discussed allegory. She understands the animal stereotypes fit people, just thinks it's weird the humans aren't questioning talking animals. Asked if she had considered that might be something the author wanted people to puzzle over - why represent Russians as animals? She struggled. Maybe do journaling activity that has students use allegory to describe school scene? Might be asking for trouble with that, but I do like the initial idea. Difficult for her to put herself in author's shoes?

Noticed she seems pretty distracted by phone lately. Asked if anything exciting or stressful was happening. Doesn't appear so, or she's not saying. Wonder if the story engagement is not here.

\section{Esperanza}

What's going well: Likes the reading out loud. Asked why. Sounds better when I do it. Asked if she gives characters voices in her head. Said yes, but they're not as good. Asked what she meant. Said it's hard to know when a character is angry or being sneaky, but she can tell when I do it. Difficultly with context of dialogue? I wonder if that comes from not understanding characters or character motivation, or if it's the situation or satire? Asked her to mark confusing parts next time to show specific example. Asked about mapping. Pictures are fun, doesn't like the analysis. 
Asked if it helps her keep track of plot? Yes. Asked if she is able to summarize and narrow down important scenes easier? Yes. What about analysis is bothering her? What the author was saying about the situation. I wonder if more allegorical practice would help, or if she needs more information on the historical connections?

What isn't going well? Journaling on days where she is absent. Hard for her to catch up and complete work on top of other daily activities. Talked about her coming in during flex for help. Doesn't like journaling during silent reading. Why? Can't make all the connections to history or morals that I do when I read and comment. Suggested she try to imagine herself as one of the characters in the chapter. How would she feel if she was Boxer in Chapter 2? What if she were the cows whose milk was taken? If she were Napoleon, how would she feel about the other animals? Said she'd try. Wasn't very convincing.

Discussed her struggles with finishing assignments and turning them. Talked about home issues; relationship ended a few weeks earlier. Claims she's starting to catch up on work. Seems more optimistic, and she's less withdrawn during class, but I still haven't seen her doing any extra work. Doesn't come in during flex, despite asking if she wants to get help.

\section{Amelia}

Didn't have to even ask about mapping - said she preferred this way to take notes. Asked what was better. Liked the group part where they could decide what qualified as important enough to draw. Asked about silent reading vs me reading out loud. Likes it when I read. Asked why. Said she doesn't know, it's just better. Is she able to focus when she reads? Yes. Hear character voices? Yes. Remember plot and characters? Yes. Asked if there was anything she could specifically tell me that was beneficial when I read vs her reading. Nope. ...who knows? Maybe it's more relaxing for her. Maybe she'll be able to articulate it later. 
Asked how she felt discussing reading as class and in groups. Prefers meeting in small groups before talking as a class. Lets her prepare.

Asked what she didn't like. Same weekly pattern. Bored just reading and talking. Will have to think about ways to help that.

\section{APPENDIX C \\ Sample Analysis of Homework and In-Class Activities}

Assignments and tasks were organized into the following categories: Homework Recall (HR), Homework Analysis (HA), Homework Synthesis (HS), Quizzes (Q), Tests (T), and Group Work (GW). Homework Recall (HR) includes assignments that ask students to recall textual events or information. Homework analysis (HA) are assignments that require students to examine texts closely to determine meaning or connections that are not readily apparent to readers. Homework Synthesis (HS) are assignments that require students to combine ideas across texts, essays, or readings to find common themes or ideas.

Alicia assigned each assignment or task to a category and then analyzed each task for patterns and concepts. The two patterns that had already emerged prior to the study for the three focal students were the frequency of completed assignments and the performance level of those assignments. Alicia wondered if making strategic changes to this unit would increase the frequency of completion and the quality of class assignments and activity engagement from the three ELL focal students. The codes Completed (C), Partially Completed (PC), or Not Completed (NC), as well as if they were Above Satisfactory (AS), Satisfactory (S), or Below Satisfactory (BS) were created. She also noted if the assignment and activities were completed Individually (I) or as Group Work (GW). When student interviews and conferences were 
conducted, Alicia observed and noted whether the student appeared Positive (P) or Negative (N) about their understanding and abilities. A typical coding example follows:

\begin{tabular}{|l|l|}
\hline Assignment: Animal Farm Ch 3 Story Mapping, Valeria \\
\hline Category & $\mathrm{HR}, \mathrm{HA}, \mathrm{HS}$ \\
\hline Completion & $\mathrm{C}$ \\
\hline Assignment Type & $\mathrm{GW}$ \\
\hline Assessment & $\mathrm{HR}=\mathrm{AS} ; \mathrm{HA}=\mathrm{AS} ; \mathrm{HS}=\mathrm{S}$ \\
\hline Notes & $\begin{array}{l}\text { Major events pictured. Analysis between previous character actions and } \\
\text { motivations clear; identified possible foreshadowing. Difficulty } \\
\text { connecting characters in story to nonfiction articles about Soviet } \\
\text { Union/Stalin. }\end{array}$ \\
\hline
\end{tabular}

Completion Rates and Assignment Scores for Focal ELLs

\begin{tabular}{|l|l|l|l|l|l|l|l|l|l|}
\hline & $\begin{array}{l}\text { Animal } \\
\text { Farm } \\
\text { Pretest }\end{array}$ & $\begin{array}{l}\text { Journal } \\
\text { Entry 1 }\end{array}$ & $\begin{array}{l}\text { Rhetorical } \\
\text { Device } \\
\text { Notes }\end{array}$ & $\begin{array}{l}\text { Animal } \\
\text { Farm Ch 1 } \\
\text { Map }\end{array}$ & $\begin{array}{l}\text { Animal } \\
\text { Farm Ch 1 } \\
\text { Quiz }\end{array}$ & $\begin{array}{l}\text { Journal } \\
\text { Entry 6 }\end{array}$ & $\begin{array}{l}\text { Animal } \\
\text { Farm } \\
\text { Ch 9 } \\
\text { Map }\end{array}$ & $\begin{array}{l}\text { Animal } \\
\text { Farm Ch 9 } \\
\text { Quiz }\end{array}$ & $\begin{array}{l}\text { Allegory } \\
\text { Synthesis } \\
\text { Assignment }\end{array}$ \\
\hline Amelia & $4 / 10$ & $10 / 10$ & $10 / 10$ & $20 / 20$ & $16 / 20$ & $10 / 10$ & $20 / 20$ & $20 / 20$ & $18 / 20$ \\
\hline Esperanza & $2 / 10$ & $0 / 10(\mathrm{NC})$ & $7 / 10(\mathrm{PC})$ & $10 / 20(\mathrm{PC})$ & $8 / 20$ & $9 / 10$ & $20 / 20$ & $16.5 / 20$ & $16 / 20$ \\
\hline Valeria & $4 / 10$ & $5 / 10(\mathrm{PC})$ & $0 / 10(\mathrm{NC})$ & $18 / 20$ & $14 / 20$ & $10 / 10$ & $20 / 20$ & $18 / 20$ & $18 / 20$ \\
\hline
\end{tabular}

\section{APPENDIX D}

\section{Sample Transcription of Student Interviews}

Alicia: So, tell me, how is your experience with the new note-taking process?

Amelia: Okay. It's okay.

Alicia: Do you like it better than the last method?

Amelia: Yeah. It's, uh, better.

Alicia: How so? Can you explain?

Amelia: It's like pictures, which help me remember. And we talk about the chapters and pictures.

Alicia: Why is that better than the last method? 
Amelia: I dunno. It's like, we talk about it and then draw it. Like, I can, like, um, [pause]

remember what's happened.

Alicia: It was harder to remember before?

Amelia: Yeah. I didn't know what I wrote. Like, I wrote stuff down, ya know? But I would read

it and I wouldn't remember it.

Alicia: Do you mean you would take notes, but then you couldn't remember why you wrote it?

Or you couldn't remember the part that you wrote happening in the story?

Amelia: Why.

Alicia: That's great. What about the class discussion of what we choose to draw? Does that help?

Amelia: Yeah.

Alicia: Can you explain why?

Amelia: Um... [pause] [laugh] I dunno.

Alicia: [laughs] That's okay, that's okay. During the old way, did you write down as much?

Amelia: [shakes head "no"]

Alicia: Do you know why you write down more now?

Amelia: I dunno. We talk about it, I guess.

Alicia: Why does that help? Why does it make you write more?

Amelia: We go over what's important.

Alicia: We would do that before, though.

Amelia: Yeah, but, um, we talk about a lot. [laughs]

Alicia: So, the drawing helps summarize what we talk about?

Amelia: Yeah. I see it and it helps me remember it. It's like a comic book. 
Alicia: Do you think drawing it matters? I mean, if we had just agreed upon the events that were important and wrote those down - would that have been as effective?

Amelia: I like the drawing.

Alicia: So tell me, how do you like the new way we take notes?

Esperanza: Dude, it's soooo much better.

Alicia: [laughs] Okay, that's good! Why's it better?

Esperanza: We're not writing so much.

Alicia: Why does writing less help?

Esperanza: It's like, before, we would just write so much it felt like we were just repeating the whole thing.

Alicia: You didn't like that? Or it wasn't helpful?

Esperanza: Both. Like, I ain't got time to write all that or go over all that and remember it.

Alicia: Why do the drawings help?

Esperanza: It's just the important stuff, ya know? Like, we don't talk about every little thing. And drawing it is so much better than writing it.

Alicia: Why is that?

Esperanza. I don't know. Like, it's not as boring. [laughs]

Alicia: Do you think it helps you do better on your assignments? Your grades have improved from the last unit.

Esperanza. For sure.

Alicia: Why do you think it's helping?

Esperanza: We talk about it and we draw the important stuff. We write why one square leads to

the next.

ITJ, 2019 Volume 16, Number 1 
Alicia: You like discussing it as a class?

Esperanza: Yep.

Valeria: Sorry about yesterday.

Alicia: It's okay. You were absent. No big deal. I just wanted to check in and see how you were doing with the note-taking and activities.

Valeria: Oh. [Pause] I like it.

Alicia: What part do you like?

Valeria: We talk about stuff together.

Alicia: For the notes or assignments?

Valeria: Um, both, I guess.

Alicia: Is it more helpful than how we use to do things?

Valeria: Yeah.

Alicia: Can you explain why it's better? Why does the group work help?

Valeria: Uh... [pause] When I read I don't get it. It helps to talk. They help me get it.

Alicia: The other students?

Valeria: And you.

Alicia: What do I do that helps?

Valeria: When you read.

Alicia: What's different about when I read versus when you read?

Valeria: You do voices. Like, if something is bad I can tell, um, by how you sound.

Alicia: Does doing the story maps help? Or is the reading and talking helping the most?

Valeria: They help me remember. I couldn't remember the pigs until we drew them.

Alicia: Napoleon and Snowball? 
Valeria: Yeah.

Alicia: Why did drawing help?

Valeria: They were just pigs. Like, I knew pigs were doing something, but I didn't see them like

humans. When we drew them I made Snowball white and Napoleon brown with horns. It was

easier to tell them apart so I knew why they didn't get along.

Alicia: Even when we read you were able to keep them separate?

Valeria: Yeah. We drew them and wrote down what they were doing. So when a pig did something bad I knew it was Napoleon.

\section{APPENDIX E}

\section{Focus Student Interview Questions}

Alicia's Guiding Question for Interviews: What process do I want ELLs to use when they read, annotate, or take notes?

Pre Prepared

- What is going well about your reading?

- What are you struggling with?

- Is there anything that is confusing you?

- Did you participate in group discussion today? Why/why not?

- Can you summarize what we/you read today?

Students:

- Can you describe what usually goes through your mind as you read?

- Can you explain how you typically take notes? What is your process, start to finish?

- Explain the process you and your group follow to take the story mapping notes. 


\section{APPENDIX F}

\section{Sample of Student Story Mapping Progress}

1st Attempt at Story Mapping with Teacher Markup: The Secret Life of Walter Mitty

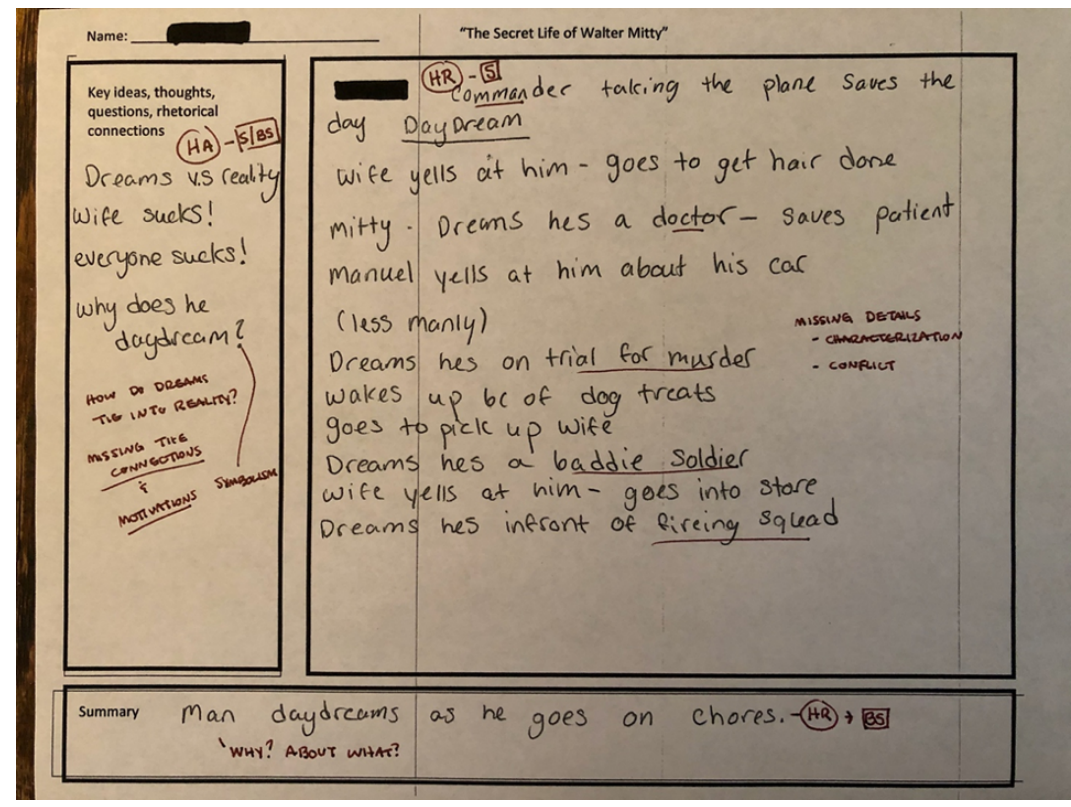

$3^{\text {rd }}$ Attempt at Story Mapping with Teacher Markup: Animal Farm

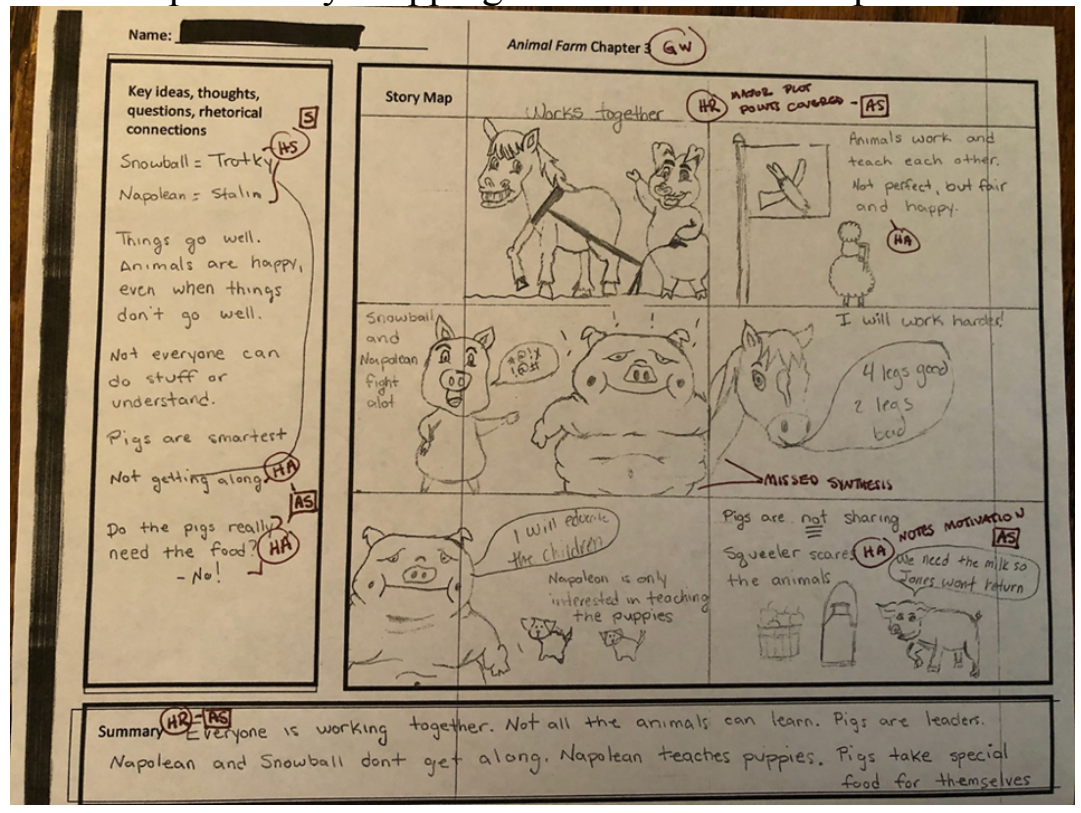

${ }^{1}$ Pseudonym

${ }^{2}$ Pseudonym

Strategies for ELs at secondary level 